\title{
Self-collection based HPV testing for cervical cancer screening among women living with HIV in Uganda: a descriptive analysis of knowledge, intentions to screen and factors associated with HPV positivity
}

Sheona M. Mitchell ${ }^{1}$, Heather N. Pedersen ${ }^{1}$, Evelyn Eng Stime ${ }^{1}$, Musa Sekikubo ${ }^{2}$, Erin Moses ${ }^{3}$, David Mwesigwa ${ }^{4}$, Christine Biryabarema ${ }^{2}$, Jan Christilaw ${ }^{5}$, Josaphat K. Byamugisha ${ }^{2}$, Deborah M. Money ${ }^{3}$ and Gina S. Ogilvie ,3,5* $^{*}$

\begin{abstract}
Background: Women living with HIV (WHIV) are disproportionately impacted by cervical dysplasia and cancer. The burden is greatest in low-income countries where limited or no access to screening exists. The goal of this study was to describe knowledge and intentions of WHIV towards HPV self-collection for cervical cancer screening, and to report on factors related to HPV positivity among women who participated in testing.

Methods: A validated survey was administered to 87 HIV positive women attending the Kisenyi Health Unit aged 30-69 years old, and data was abstracted from chart review. At a later date, self-collection based HPV testing was offered to all women. Specimens were tested for high risk HPV genotypes, and women were contacted with results and referred for care. Descriptive statistics, Chi Square and Fischer-exact statistical tests were performed.
\end{abstract}

Results: The vast majority of WHIV (98.9\%) women did not think it necessary to be screened for cervical cancer and the majority of women had never heard of HPV (96.4\%). However, almost all WHIV found self-collection for cervical cancer screening to be acceptable. Of the 87 WHIV offered self-collection, 40 women agreed to provide a sample at the HIV clinic. Among women tested, 45\% were oncogenic HPV positive, where HPV 16 or 18 positivity was 15\% overall.

Conclusions: In this group of WHIV engaged in HIV care, there was a high prevalence of oncogenic HPV, a large proportion of which were HPV genotypes 16 or 18, in addition to low knowledge of HPV and cervical cancer screening. Improved education and cervical cancer screening for WHIV are sorely needed; self-collection based screening has the potential to be integrated with routine HIV care in this setting.

Keywords: Human papillomavirus, HIV, Cervical cancer, Self-collection, Screening

* Correspondence: gina.ogilvie@cw.bc.ca

'University of British Columbia, Vancouver, BC, Canada

${ }^{3}$ Women's Health Research Institute, Vancouver, BC, Canada

Full list of author information is available at the end of the article 


\section{Background}

Cervical cancer is a largely preventable and curable disease that affects over half a million women each year, with the greatest impact in low and middle income countries (LMIC) where access to screening, diagnosis, and treatment are extremely limited [1]. As a result, most people in these regions are diagnosed with cervical cancer at a late stage [2]. With this delayed diagnosis, more resources are required for treatment, which increases demands on already overloaded tertiary care centers. Uganda has one of the highest age-standardized incidence rates of cervical cancer globally (41.7/100 000 person-years) at almost six times the rate in high income countries, in addition to a high prevalence of human immunodeficiency virus (HIV) [3]. It is well established that oncogenic types of the human papillomavirus (HPV) are the main causative agents of cervical cancer [4]. Primary prevention with the HPV vaccine has not been rolled out in most LMIC including Uganda, and the risk for cervical cancer will remain for decades [5]. Characterized by suppressed immune function, women living with HIV (WHIV) are more likely to have persistent HPV infection and simultaneous infection with more than one strain of HPV putting them at higher risk for cervical dysplasia and invasive cervical cancer [6-8]. Cervical cancer is an AIDS-defining illness [9] that remains a threat in the era of combination antiretroviral treatment (cART) which have little to no effect on the natural history of cervical cancer [7, 10].

In most LMIC, visual inspection with acetic acid (VIA) is the standard of care for cervical cancer screening, which requires trained health personnel to perform pelvic exams, and willingness by women to attend a clinic and undergo an invasive examination. This is a barrier to effective cervical cancer screening for many women in LMIC settings [11]. VIA brings additional challenges in WHIV who are more likely to have false positive examinations that lead to unnecessary and potentially harmful treatments. An innovative and feasible method of cervical cancer screening is emerging with the introduction of selfcollection by vaginal swab for oncogenic HPV DNA testing. By avoiding the need for a pelvic examination this technology can significantly decrease the demand on trained healthcare providers with additional benefits of low cost and minimal infrastructure requirements [8, 12, 13]. With HPV DNA testing there is also the option to offer self-collection based screening where sample collection can be performed by women in their own homes, further reducing barriers. The Advances in Screening and Prevention in Reproductive Cancers (ASPIRE) project, based in Uganda, was developed to examine innovations in cancer prevention for women in LMIC [14-17]. Although other studies in sub-Saharan Africa have examined attitudes of WHIV to cervical cancer screening, none have specifically addressed self-collection of HPV as a screening modality in this population [18]. To further understand the attitudes of WHIV towards self-collected specimens for cervical cancer screening, we surveyed WHIV in Kisenyi, Uganda, to explore their intention to participate in self-collection based cervical cancer screening, and offered women self-collection based testing at the local HIV clinic. This information will guide programming to engage women with HIV in cervical cancer screening.

\section{Methods \\ Design, setting and study population}

The study design was a cross-sectional survey of knowledge, attitudes and behaviours towards self-collected sampling for cervical cancer screening in WHIV, who were then invited to participate in self-collection based screening. Interviews with WHIV and screening were conducted at a satellite HIV clinic of the Infectious Disease Institute (IDI) located at the Kisenyi Health Unit in an impoverished area of Kampala, Uganda. WHIV aged 30-69 years old attending a routine appointment for their HIV care were invited to participate by a member of the Friends Council, an HIV positive peer group between July and August 2013. An additional inclusion criterion was access to a mobile telephone. Women were excluded if they had previously had a hysterectomy, cervical cancer or they were unable to provide consent. Ethics approval for the study was obtained from the Research Ethics Board of the University of British Columbia (H09-02935-A013) and Makerere University (H13-02117).

\section{Survey \& chart review}

A structured questionnaire was created based on a previously validated survey using the Theory of Planned Behaviour exploring women's intentions to provide a self-collected specimen for cervical cancer screening [14]. Items were reviewed with local and international experts in HIV and women's health, revised and pilot tested prior to inclusion in the survey. The revised survey with additional HIV items was translated into the local language, Luganda, piloted in the community and then edited and revised based on feedback for clarity. Data was abstracted from each participant's chart from the HIV clinic which included clinical information such as CD4 count, time since last appointment and blood work, World Health Organization (WHO) HIV disease stage [19], as well as type and duration of cART. In this clinical setting, women do not necessarily receive clinical blood work at each visit, but only if symptomatic or not on cART. Data from interviews and corresponding chart review were entered into an Access database created from survey questions and analyzed using SPSS (v14). 


\section{Study procedures}

In November 2013, local research assistants fluent both in English and Luganda were identified by the Ugandan ASPIRE research coordinator and trained in collaboration with the Canadian ASPIRE research team. In a private location that ensured patient confidentiality and allowed one-on-one interviews by the local research assistant, the survey participant's primary language was used to explain the study, obtain informed consent, and complete the survey. After participants completed initial knowledge survey questions, the procedure of self-collecting a sample for HPV testing was explained by the local research assistant using a diagram of the swab, the genital tract, and cartoons of how to obtain self-collected sample. Surveys were completed by consenting study participants over a threeweek period. Following completion of all survey and data recording, a workshop tailored from survey responses was held for study participants as an educational intervention about HIV and cervical cancer, HPV, and cervical cancer screening. This workshop also functioned to inform participants of relevant findings.

In February-June 2014, all participants were contacted by a nurse from the HIV clinic by phone and invited to make an appointment to participate in self-collection based HPV testing at the HIV clinic. Women who could not be reached by phone were approached at their next HIV follow up visit. At the time of their clinic visit, women were instructed on how to use the self-collected vaginal swab and asked to provide a sample in a private room at the clinic. Specimens were tested for high risk HPV (genotypes 16, 18, 31, 33, 35, 39, 45, 52, 56, 58, 59 and 66), Neisseria gonorrhoeae and Chlamydia trachomatis with real-time PCR. Women who tested HPV positive were contacted by phone with results and scheduled a colposcopy appointment for assessment at Mulago Hospital, a tertiary care center. Women who tested positive for $N$. gonorrhoeae and $C$. trachomatis were offered antibiotic treatment and counseling.

\section{Data analysis}

Descriptive statistics for all survey questions, chart review data, and screening results were generated for all participants. Chi-square or Fisher's exact test were used to compare factors of interest between $\mathrm{HPV}+$ and HPVwomen that participated in screening. Unadjusted odds ratios (OR) were calculated for all variables that reached significance of $p>0.05$.

\section{Results}

\section{Population demographics}

In total 84 of 87 study participants completed the survey. Details for the demographic characteristics and chart review data of WHIV are captured in Table 1. WHIV in our study population were considered as engaged with health care with over 92.9\% having attended for HIV care and monitoring in the past 6 months from chart review. Only $29.6 \%$ of women had been living with HIV for over 5 years, and $51.9 \%$ had a CD4 count over 350. The majority of women, 75.9\%, had HIV WHO stage I or II disease [19] at the time of the study with $69 \%$ on an ART regimen.

\section{Knowledge \& intention to be screened}

The survey responses for the knowledge, attitudes and behaviours among WHIV in this study are captured in Table 2. Less than $20 \%$ of WHIV reported having received education about cervical cancer screening, and over one third stated they never had been offered or advised to be screened. Most women had never heard of HPV (96.4\%), while more than $60 \%$ of WHIV knew they were at increased risk for cervical cancer due to their $\mathrm{HIV}$ and were aware they needed to be screened. Of those that were aware of HPV, WHIV often knew that HPV risk was linked to sexual intercourse but unaware that HPV causes cervical cancer. Only 25\% of WHIV reported condom use as their primary method of contraception, and the pill was the most popular method of contraception (27.4\%), and $23.8 \%$ reported no contraception use.

Overall 98.8\% of WHIV intended to provide HPV selfcollected specimens for cervical cancer screening. Only one woman indicated that she would not be willing to self-collect, and this was because she was pregnant at the time of the study. Despite the high acceptability of self-collection among WHIV, the majority of women did not think it was necessary to be screened for cervical cancer (98.8\%). Similarly, perceived risk of HPV was low (8.3\%), while $44 \%$ of WHIV were unsure if they were at risk. The vast majority of women (95.2\%) did not see embarrassment or concerns of how to collect the specimen properly as barriers to screening; nor were they concerned others would perceive them to have cervical cancer if they were tested for HPV (97.6\%), and 69.9\% found it acceptable for an outreach worker drop off a swab at their home.

\section{Results from HPV testing}

Of the 87 WHIV in the study, 40 (46.0\%) were able to attend the clinic to provide a self-collected sample for high risk HPV testing. A total of 18/40 (45.0\%) tested positive for one of the 12 high risk HPV genotypes and of those $6(15.0 \%)$ women were positive for HPV strains 16 or 18. Among HPV positive women, 5/18 attended follow up colposcopy assessment, one of whom was positive for HPV 16/18, and all women were negative for cervical dysplasia. There were no cases of $N$. gonorrhoeae or C. trachomatis in the study population. Factors associated 
Table 1 Demographics and chart review characteristics of WHIV

\begin{tabular}{|c|c|c|}
\hline Variable & & $\begin{array}{l}\text { Total } N=87 \\
N(\%)\end{array}$ \\
\hline \multirow[t]{8}{*}{ Age } & $30-35$ & $36(43.4)$ \\
\hline & $36-40$ & 29(34.9) \\
\hline & $41-45$ & $7(8.4)$ \\
\hline & $46-50$ & $5(6)$ \\
\hline & $51-55$ & $2(2.4)$ \\
\hline & $56-60$ & $4(4.8)$ \\
\hline & $61-69$ & 0 \\
\hline & Missing & 4 \\
\hline \multirow[t]{5}{*}{ Marital status } & Single & $11(13.3)$ \\
\hline & Married/Common law & 29(34.9) \\
\hline & Separated/Divorced & $31(37.3)$ \\
\hline & Widowed & $12(14.5)$ \\
\hline & Missing & 4 \\
\hline \multirow{5}{*}{$\begin{array}{l}\text { Highest school } \\
\text { level completed }\end{array}$} & No schooling/some primary & $34(40.5)$ \\
\hline & Primary/some secondary & $46(54.8)$ \\
\hline & $\begin{array}{l}\text { Completed secondary } \\
\text { school }\end{array}$ & $2(2.4)$ \\
\hline & $\begin{array}{l}\text { Further studies (trade/ } \\
\text { college/university) }\end{array}$ & $2(2.4)$ \\
\hline & Missing & 3 \\
\hline \multirow[t]{3}{*}{ Work outside home } & No & $23(27.4)$ \\
\hline & Yes & $61(72.6)$ \\
\hline & Missing & 3 \\
\hline \multirow[t]{4}{*}{ Accommodation } & Rent & $61(73.5)$ \\
\hline & Own & $22(26.5)$ \\
\hline & No place to live & 0 \\
\hline & Missing & 4 \\
\hline \multirow[t]{3}{*}{ Religion } & $\begin{array}{l}\text { Christian (various } \\
\text { denominations) }\end{array}$ & $67(79.8)$ \\
\hline & Muslim & $17(20.2)$ \\
\hline & Missing & 3 \\
\hline \multirow{4}{*}{$\begin{array}{l}\text { Ever had a pelvic } \\
\text { examination }\end{array}$} & No & $71(85.5)$ \\
\hline & Yes & $12(14.5)$ \\
\hline & I don't know & 0 \\
\hline & Missing & 4 \\
\hline \multirow[t]{2}{*}{ Ever had sexual intercourse } & Yes & $84(100)$ \\
\hline & Missing & 3 \\
\hline $\begin{array}{l}\text { Age at first sexual } \\
\text { intercourse, median (IQR) }\end{array}$ & & $16(4)$ \\
\hline $\begin{array}{l}\text { Number of pregnancies, } \\
\text { median (IQR) }\end{array}$ & & $4(3)$ \\
\hline \multirow[t]{4}{*}{ Years since HIV+ confirmed } & $<1$ year & 13(16.0) \\
\hline & $1-2$ years & 24(29.6) \\
\hline & $3-4$ years & $20(24.7)$ \\
\hline & $\geq 5$ years & $24(29.6)$ \\
\hline
\end{tabular}

Table 1 Demographics and chart review characteristics of WHIV (Continued)

\begin{tabular}{lll}
\hline & Missing & 6 \\
Mean Age diagnosed (SD) & & $33.96(6.54)$ \\
Most recent HIV & $<6$ months & $78(92.9)$ \\
appointment & $\geq 6$ months & $6(7.1)$ \\
& Missing & 3 \\
Most recent blood work & $<6$ months & $39(44.8)$ \\
& $\geq 6$ months & $42(51.9)$ \\
Recent CD4 Count & Missing & 3 \\
(Cells/mm ${ }^{3}$ ) & $<350$ & $39(48.1)$ \\
& $\geq 350$ & $42(51.9)$ \\
WHO Stage & Missing & 3 \\
& I & $31(37.3)$ \\
& II & $32(38.6)$ \\
& III & $12(14.5)$ \\
On ARV & IV & $8(9.6)$ \\
Mean duration of ARV & Missing & 4 \\
& & $40.0(34.77)$ \\
& Yes & $58(69.0)$ \\
& No & $26(31.0)$ \\
\hline
\end{tabular}

with HPV positivity are included in Table 3. WHIV who reported use of oral contraceptives were more likely to be HPV positive (OR $=6.65,95 \% \mathrm{CI}: 1.16,38.19 ; p=0.03)$ and WHIV who have had blood work within the past 6 months were more likely to be HPV positive (OR $=0.16$, 95\% CI: 0.03, 0.74; $p=0.02$ ) (Table 4).

Among WHIV who participated in the study but did not attend screening, 2 of 47 could not be reached by phone, 5 of 47 indicated that they had screened for cervical cancer elsewhere, and 40 of 47 refused to attend the clinic. The main reasons for refusal were that distance to travel was too far, not having time to attend screening, or did not show up for the scheduled appointment.

\section{Discussion}

Knowledge of HPV, cervical cancer \& intention to screen Although our population in Kisenyi was highly engaged in HIV care, less than $20 \%$ had ever received any education around cervical cancer, $96 \%$ had never heard of HPV, and almost $99 \%$ did not feel it was necessary to be screened. These findings reflect a potential lack of cervical cancer training among HIV care providers, and competing health priorities in HIV positive populations. The low percentage of women in our study who had ever had a pelvic exam (14.5\%) is further evidence of the 
Table 2 Knowledge, attitudes and behaviours among WHIV

\begin{tabular}{|c|c|c|}
\hline Variable & & $\begin{array}{l}\text { Total } N=87 \\
N(\%)\end{array}$ \\
\hline \multirow{4}{*}{$\begin{array}{l}\text { Do you know someone who } \\
\text { has had cervical cancer? }\end{array}$} & No & $48(57.1)$ \\
\hline & Yes & $9(10.7)$ \\
\hline & Don't know & $27(32.1)$ \\
\hline & Missing & 3 \\
\hline \multirow{7}{*}{$\begin{array}{l}\text { What do you think causes } \\
\text { cervical cancer? (open ended } \\
\text { question, grouped by response) }\end{array}$} & Sexual intercourse & $30(35.7)$ \\
\hline & Birth control & 17(20.2) \\
\hline & Poor hygiene & $3(3.6)$ \\
\hline & Other (ie cigarettes) & $7(8.3)$ \\
\hline & I don't know & $31(36.9)$ \\
\hline & No response & $27(32.1)$ \\
\hline & Missing & 3 \\
\hline \multirow{3}{*}{$\begin{array}{l}\text { Have you heard of Human } \\
\text { Papillomavirus (HPV)? }\end{array}$} & No & $81(96.4)$ \\
\hline & Yes & $3(3.6)$ \\
\hline & Missing & 3 \\
\hline \multirow{4}{*}{$\begin{array}{l}\text { Cervical cancer is caused } \\
\text { by HPV }\end{array}$} & No & 0 \\
\hline & Yes & $23(27.7)$ \\
\hline & I don't know & $60(72.3)$ \\
\hline & Missing & 4 \\
\hline \multirow{7}{*}{$\begin{array}{l}\text { What types of birth control } \\
\text { have you and your partner } \\
\text { used? }\end{array}$} & Condoms & $21(25.0)$ \\
\hline & Pill & $23(27.4)$ \\
\hline & Female Condom & 0 \\
\hline & Do not use & 20(23.8) \\
\hline & Not sexually active & $2(2.4)$ \\
\hline & $\begin{array}{l}\text { Other (injection, } \\
\text { norplant, IUD, etc.) }\end{array}$ & $31(36.9)$ \\
\hline & Missing & 3 \\
\hline \multirow{6}{*}{$\begin{array}{l}\text { During the last month, how } \\
\text { frequently have you used } \\
\text { condoms? }\end{array}$} & Never & $53(63.1)$ \\
\hline & Sometimes & 16(19.0) \\
\hline & Usually & $12(14.3)$ \\
\hline & Always & $2(2.4)$ \\
\hline & No having sex & $1(1.2)$ \\
\hline & Missing & 3 \\
\hline \multirow{4}{*}{$\begin{array}{l}\text { Being tested for HPV is a way } \\
\text { to screen for cervical cancer }\end{array}$} & No & $3(3.6)$ \\
\hline & Yes & $37(44.6)$ \\
\hline & I don't know & $43(51.8)$ \\
\hline & Missing & 4 \\
\hline \multirow{4}{*}{$\begin{array}{l}\text { Women with HIV are at } \\
\text { increased risk for cervical } \\
\text { cancer }\end{array}$} & No & 0 \\
\hline & Yes & $51(61.4)$ \\
\hline & I don't know & $32(38.6)$ \\
\hline & Missing & 4 \\
\hline \multirow{4}{*}{$\begin{array}{l}\text { Screening for cervical cancer } \\
\text { in women with HIV can } \\
\text { prevent developing cancer } \\
\text { of the cervix }\end{array}$} & No & $3(3.6)$ \\
\hline & Yes & $52(61.9)$ \\
\hline & I don't know & $29(34.5)$ \\
\hline & Missing & 3 \\
\hline
\end{tabular}

Table 2 Knowledge, attitudes and behaviours among WHIV (Continued)

\begin{tabular}{|c|c|c|}
\hline \multirow{4}{*}{$\begin{array}{l}\text { Ever receive education } \\
\text { about cervical cancer? }\end{array}$} & No & $66(80.5)$ \\
\hline & Yes & 15(18.3) \\
\hline & Don't know & $1(1.2)$ \\
\hline & Missing & 5 \\
\hline \multirow{3}{*}{$\begin{array}{l}\text { Cervical cancer screening } \\
\text { ever advised }\end{array}$} & No & $30(35.7)$ \\
\hline & Yes & $54(64.3)$ \\
\hline & Missing & 3 \\
\hline \multirow{6}{*}{$\begin{array}{l}\text { Reason no pelvic exam } \\
\text { (open ended question, } \\
\text { grouped by response) }\end{array}$} & $\begin{array}{l}\text { Embarrassed about } \\
\text { a pelvic exam }\end{array}$ & $2(2.7)$ \\
\hline & $\begin{array}{l}\text { Thought it would } \\
\text { be painful }\end{array}$ & $5(6.8)$ \\
\hline & Did not have time & 0 \\
\hline & Other & $2(2.7)$ \\
\hline & $\begin{array}{l}\text { Not offered a } \\
\text { pelvic exam }\end{array}$ & $64(87.7)$ \\
\hline & Missing & 14 \\
\hline \multirow[t]{4}{*}{ Preferred place to self-collect } & Home & $33(39.3)$ \\
\hline & Kisenyi Health Center & $33(39.3)$ \\
\hline & Both & $18(21.4)$ \\
\hline & Missing & 4 \\
\hline \multirow{4}{*}{$\begin{array}{l}\text { I would be embarrassed to } \\
\text { collect a sample at home }\end{array}$} & No & $79(95.2)$ \\
\hline & Yes & 0 \\
\hline & Not sure & $4(4.8)$ \\
\hline & Missing & 4 \\
\hline \multirow{4}{*}{$\begin{array}{l}\text { I am worried that I would not } \\
\text { collect the sample properly }\end{array}$} & No & $70(84.3)$ \\
\hline & Yes & $2(2.4)$ \\
\hline & Not sure & $11(13.3)$ \\
\hline & Missing & 4 \\
\hline \multirow{4}{*}{$\begin{array}{l}\text { I am afraid that HPV testing will } \\
\text { show that I have cervical cancer }\end{array}$} & No & $61(72.6)$ \\
\hline & Yes & $5(6.0)$ \\
\hline & Not sure & $18(21.4)$ \\
\hline & Missing & 4 \\
\hline \multirow{4}{*}{$\begin{array}{l}\text { I am afraid HPV testing will } \\
\text { make other people think I } \\
\text { have cervical cancer }\end{array}$} & No & $82(97.6)$ \\
\hline & Yes & 0 \\
\hline & Not sure & $2(2.4)$ \\
\hline & Missing & 3 \\
\hline \multirow{4}{*}{$\begin{array}{l}\text { I am worried self-collecting a } \\
\text { sample will be painful }\end{array}$} & No & $69(82.1)$ \\
\hline & Yes & 2(2.4) \\
\hline & Not sure & $13(15.5)$ \\
\hline & Missing & 3 \\
\hline \multirow{5}{*}{$\begin{array}{l}\text { I would be willing to have an } \\
\text { outreach worker drop off a swab }\end{array}$} & No & $22(26.5)$ \\
\hline & Yes & $58(69.9)$ \\
\hline & Not sure & 3(3.6) \\
\hline & Missing & 3 \\
\hline & No & $81(9$ \\
\hline
\end{tabular}


Table 2 Knowledge, attitudes and behaviours among WHIV (Continued)

\begin{tabular}{lll}
\hline $\begin{array}{l}\text { I would need my husband/ } \\
\text { partner's approval to collect } \\
\text { the sample }\end{array}$ & Yes & $3(3.6)$ \\
$\begin{array}{l}\text { My religion/spiritual belief } \\
\text { would affect my decision } \\
\text { to be screened }\end{array}$ & No & 3 \\
& Yes & $84(100)$ \\
& Mot sure & 0 \\
& No & 0 \\
I do not thing it is necessary to & No & 3 \\
be screened for cervical cancer & Yes & 0 \\
& Not sure & $83(98.8)$ \\
& Missing & $1(1.2)$ \\
Would you be willing to go & No & 3 \\
to Kisenyi Health Center if \\
the self-collected sample & Yes & $1(1.2)$ \\
was found abnormal & Not sure & $83(98.8)$ \\
& Missing & 0 \\
I feel I am at risk for & No & 3 \\
having HPV & Yes & $40(47.6)$ \\
& Not sure & $7(8.3)$ \\
& Missing & $37(44.0)$ \\
& & 3
\end{tabular}

potential impact that offering HPV self-collection as part of routine HIV care could have on WHIV to enhance the uptake of cervical cancer screening. Others have emphasized the need to integrate cervical cancer screening into routine HIV care for WHIV and have documented the impact of missed opportunities for education about cervical cancer by HIV care providers [20]. Despite this, data from South Africa, a country with significantly more health resources than Uganda, illustrates the positive impact of increased infrastructure on health education with over $85 \%$ of WHIV aware of cervical cancer screening [21].

\section{Self-collection based HPV testing for cervical cancer screening}

In this group of WHIV engaged in care, there was a high prevalence of oncogenic HPV types (45.0\%), a large proportion of which were HPV 16 or 18 (15\%). This is much higher than other studies that ASPIRE has conducted in Kisenyi where HPV positivity rates among HIV negative women was only $28.9 \%$, of which $5.3 \%$ were HPV 16 or 18 [22]. Our HIV positive population was more likely to live or work outside of Kisenyi, compared to past studies where self-collection was offered by community outreach workers at their homes [23, 24]. This suggests that a model for screening with selfcollection for WHIV may be more appropriately based out of a health center, as these women are already engaged in care, thereby avoiding unnecessary travel.
Unlike the present study where many women were asked to attend self-collection outside of their normal HIV appointment schedule; had screening been integrated with routine HIV care, uptake and follow-up would have undoubtedly been higher. Uptake of self-collection based screening in Kisenyi was $99 \%$ in a recent study [24], and a subgroup analysis demonstrated 95\% uptake among WHIV [22]. Similarly, we believe that the distance to the tertiary care hospital where colposcopy is conducted, as well as the time required for the additional visit were barriers to follow up assessment. Competing priorities, lack of perceived risk, and cost are likely important factors that have made colposcopy follow up adherence a challenge in this, and other studies our team has conducted in this community [24].

In our population, women who were taking oral contraceptives were more likely to be HPV positive. This is consistent with other studies, although the literature around the role of oral contraceptive on HPV positivity is unclear and in need of further study $[25,26]$. Women who had taken blood work within the last 6 months were also more likely to be HPV positive. Since blood work is usually only performed on women who are symptomatic, it is possible that HPV is more persistent in these women.

\section{Limitations and policy implications}

This study was limited by its small sample size, which prevented us from conducting further statistical testing such as logistic regression. Another limitation was that a large proportion of our original survey population was unavailable to attend screening. Due to limitations on the study timeline, we were unable to offer screening during a routine HIV clinical visit to demonstrate an integrated approach. Despite this, we feel our results demonstrate the feasibility of a self-collection based approach to screening, while underscoring the challenges of offering interventions in a siloed manner.

Despite alarmingly low levels of knowledge of HPV, global expansion of the HPV vaccine in countries including Uganda offers the opportunity for community health workers to engage and educate girls, women and their families on cervical cancer prevention. Self-collection for HPV screening has been demonstrated as a highly acceptable and effective method of cervical cancer screening, particularly in susceptible populations such as WHIV [14, 15]. This highly scalable model can be adapted and implemented in various ways to improve access using minimal infrastructure. In communitybased models for HPV self-collection, community outreach workers can be used to offer women screening at their homes or places of work. There is also huge potential for this type of screening to be offered in an integrated manner, where screening can be combined with other 
Mitchell et al. BMC Women's Health (2017) 17:4

Page 7 of 10

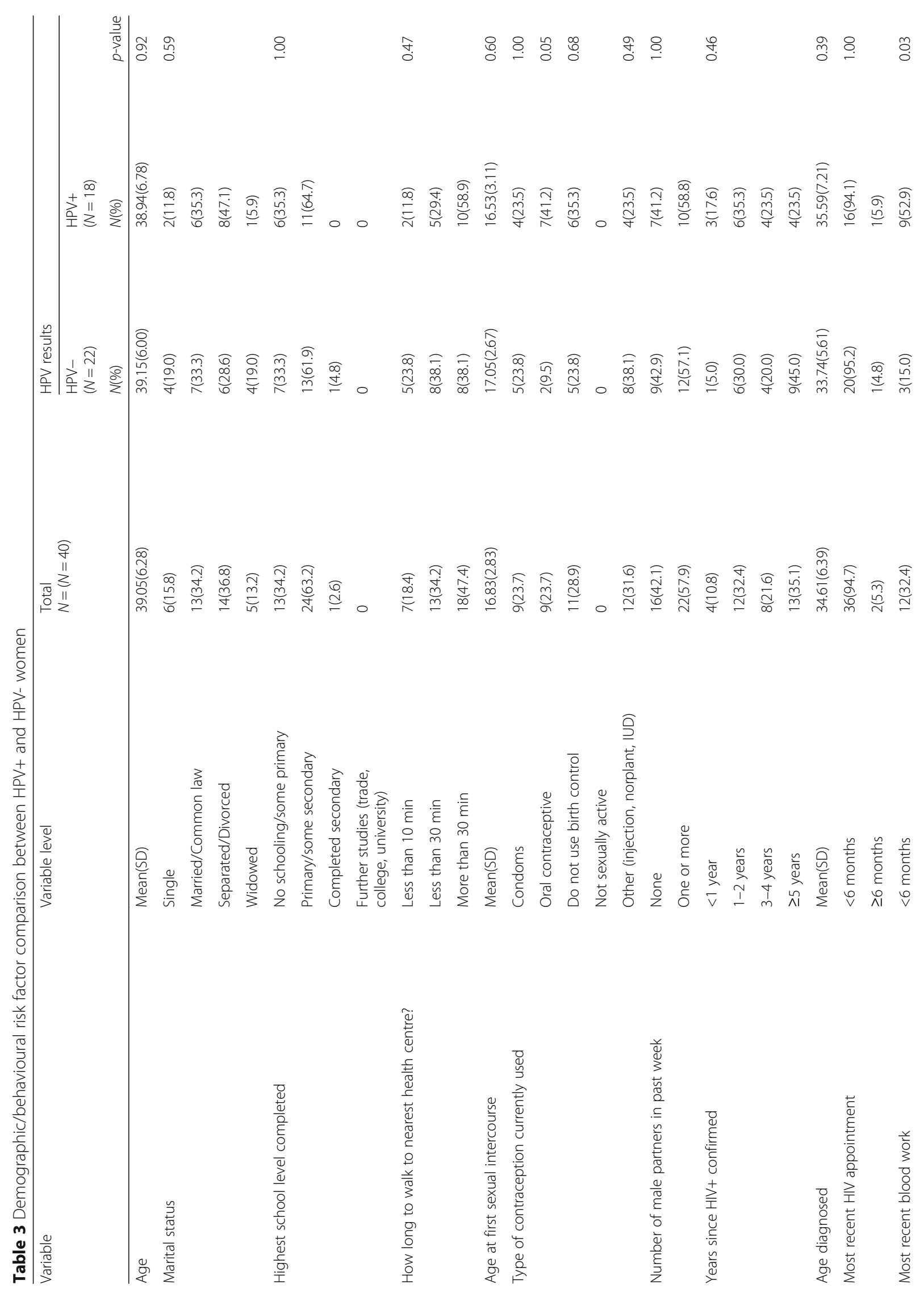




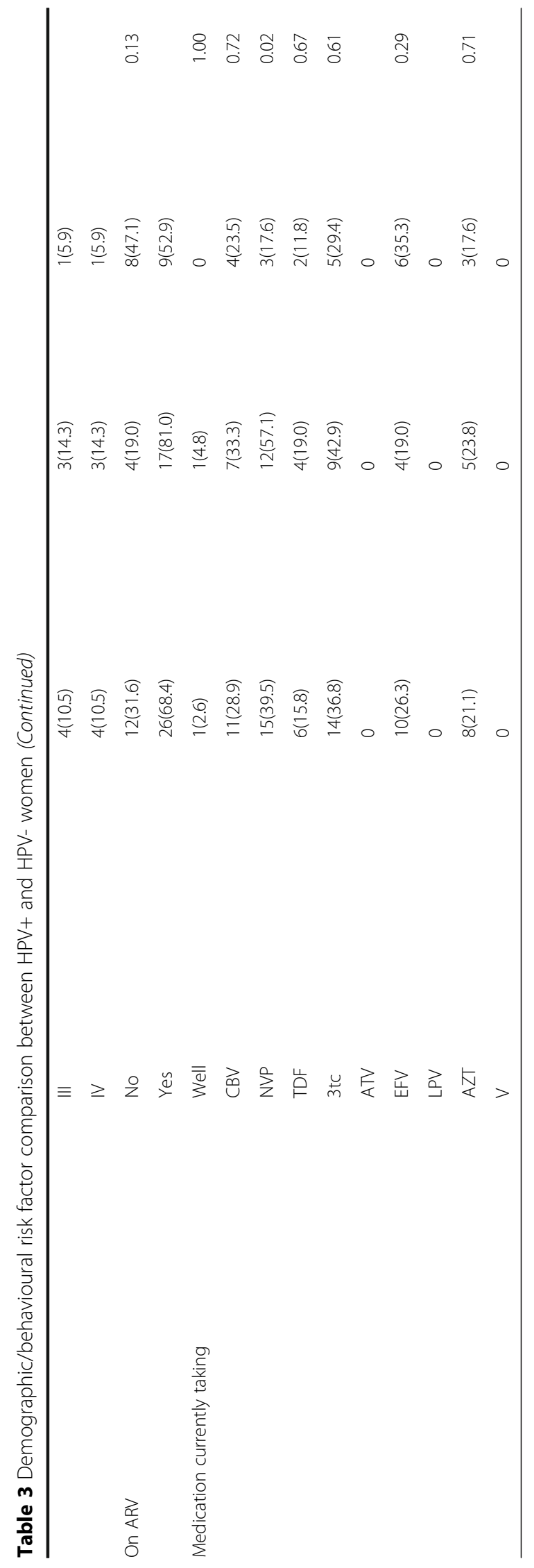


Table 4 Unadjusted odds ratio estimates for factors associated with HPV positivity

\begin{tabular}{lllll}
\hline Variable & Variable Level & Unadjusted OR & $95 \% \mathrm{Cl}$ & $p$-value \\
\hline Currently use & No & Reference & & \\
Oral contraceptive & Yes & 6.65 & $1.16-38.19$ & 0.03 \\
Most recent & $<6$ months & Reference & & \\
blood work & $\geq 6$ months & 0.16 & $0.03-0.74$ & 0.02 \\
\hline
\end{tabular}

health services such as maternal/child or reproductive health services. Given the higher rates of cervical cancer among WHIV, screening should without question be integrated with routine HIV appointments. HIV clinics are often already equipped with the necessary human resources and infrastructure needed to implement selfcollection based screening and follow up, including a laboratory where HPV testing can be performed. Of note, colposcopy and early curative treatment would need to be more readily accessible for effective scale up of a comprehensive cervical cancer screening program.

\section{Conclusions}

To not integrate prevention of cervical cancer in HIV care would do a great disservice to the accomplishments that have been made in the management of HIV. The overwhelming and growing need for accessible and effective screening in WHIV at risk for cervical cancer should compel us to look at feasible methods on a large scale. Our study of WHIV in this LMIC setting demonstrates the potential for HPV self-collection to be integrated into routine HIV care at a community level.

\begin{abstract}
Abbreviations
ASPIRE: The advances in screening and prevention in reproductive cancers project; CART: Combination antiretroviral treatment; CD4: Cluster of differentiation 4; HIV: Human immunodeficiency virus; HPV: Human papillomavirus; IDI: Infectious Disease Institute; LMIC: Low and middle income country; OR: Odds ratio; WHIV: Women living with HIV; WHO: World Health Organization
\end{abstract}

\section{Acknowledgements}

The authors would like to thank the community outreach workers, and the midwives and staff at the Infectious Disease Institute, as well as the women of Kisenyi who participated in the study.

\section{Funding}

This project was funded by the University of British Columbia Development Office, Quail Rock Foundation; the BC Centre for Disease Control Foundation for Population Health, and the Women's Health Research Institute at BC Women's Hospital and Health Centre.

\section{Availability of data and materials}

GO has full access to all of the data in the study. Re quests for data should be directed to the corresponding author.

\section{Authors' contributions}

$S M, H P, E E S, M S, E M, D M, C B, J C, J B, D M M$, and GO contributed to study design, data interpretation and generation of conclusions. EM supervised the data acquisition and HP led the data analysis. HP prepared the first draft of the manuscript and SM, HP, EES, MS, EM, DM, CB, JC, JB, DMM, and GO contributed to editing and critical analysis of the manuscript and conclusions. GO takes responsibility for the integrity of the data and the accuracy of the data analysis. All authors read and approved the final manuscript.

\section{Competing interests}

The authors declare that they have no competing interests.

\section{Consent for publication}

Not applicable.

\section{Ethics approval and consent to participate}

Ethics approval for the study was obtained from the Research Ethics Board of the University of British Columbia (H09-02935-A013) and Makerere University (H13-02117).

\section{Author details}

${ }^{1}$ University of British Columbia, Vancouver, BC, Canada. ${ }^{2}$ Makerere University, Kampala, Uganda. ${ }^{3}$ Women's Health Research Institute, Vancouver, BC, Canada. ${ }^{4}$ Kisenyi Health Centre, Kampala, Uganda. ${ }^{5}$ BC Women's Hospital and Health Centre, Box 42Room H203G - 4500 Oak Street, Vancouver, BC V6H $3 \mathrm{~N} 1$, Canada

Received: 11 September 2015 Accepted: 29 December 2016 Published online: 13 January 2017

\section{References}

1. Parkin DM, Bray F, Ferlay J, Pisani P. Global cancer statistics, 2002. CA Cancer J Clin. 2005;55(2):74-108.

2. Katahoire R, Jitta J, Kibumbi G, Murokora D, Arube Wani J, Siu G, et al. An assessment of the readiness for introduction of the HPV vaccine in Uganda. Afr J Reprod Health. 2008;12(3):159-72.

3. Namujju PB, Waterboer T, Banura C, Muwonge R, Mbidde EK, Byaruhanga R, et al. Risk of seropositivity to multiple oncogenic human papillomavirus types among human immunodeficiency virus-positive and -negative Ugandan women. J Gen Virol. 2011;92(12):2776-83. doi:10.1099/vir.0.035923-0.

4. Walboomers JM, Jacobs MV, Manos MM, Bosch FX, Kummer JA, Shah KV, et al. Human papillomavirus is a necessary cause of invasive cervical cancer worldwide. J Pathol. 1999;189(1):12-9. doi:10.1002/(SICI)10969896(199909)189:1<12::AID-PATH431>3.0.CO;2-F.

5. Maine D, Hurlburt S, Greeson D. Cervical cancer prevention in the 21st century: cost is not the only issue. Am J Public Health. 2011;101(9):1549-55.

6. Heard I, Tassie JM, Kazatchkine MD, Orth G. Highly active antiretroviral therapy enhances regression of cervical intraepithelial neoplasia in HIVseropositive women. AIDS. 2002;16(13):1799-802.

7. De Vuyst H, Lillo F, Broutet N, Smith JS. HIV, human papillomavirus, and cervical neoplasia and cancer in the era of highly active antiretroviral therapy. Eur J Cancer Prev. 2008;17(6):545-54. doi:10.1097/CEJ. Ob013e3282f75ea1.

8. Petignat P, Hankins C, Walmsley S, Money D, Provencher D, Pourreaux K, et al. Self-sampling is associated with increased detection of human papillomavirus DNA in the genital tract of HIV-seropositive women. Clin Infect Dis. 2005;41(4):527-34. doi:10.1086/432059.

9. The Centers for Disease Control and Prevention. 1993 revised classification system for HIV infection and expanded surveillance case definition for AIDS among adolescents and adults. JAMA. 1993;269(6):729-30.

10. Heard I. Prevention of cervical cancer in women with HIV. Curr Opin HIV AIDS. 2009:4(1):68-73. doi:10.1097/COH.0b013e328319bcbe.

11. Cain J, Denny L, Ngan HY. Overcoming barriers to the eradication of cervical cancer: women's health and rights. Int I Gynaecol Obstet. 2007: 97(3):232-4. doi:10.1016/j.ijgo.2007.03.004.

12. Ogilvie GS, Patrick DM, Schulzer M, Sellors JW, Petric M, Chambers K, et al. Diagnostic accuracy of self collected vaginal specimens for human papillomavirus compared to clinician collected human papillomavirus specimens: a meta-analysis. Sex Transm Infect. 2005;81(3):207-12. doi:10 1136/sti.2004.011858.

13. Snijders PJ, Verhoef VM, Arbyn M, Ogilvie G, Minozzi S, Banzi R, et al. Highrisk HPV testing on self-sampled versus clinician-collected specimens: a review on the clinical accuracy and impact on population attendance in cervical cancer screening. Int J Cancer. 2013;132(10):2223-36. doi:10.1002/ijc.27790.

14. Mitchell S, Ogilvie G, Steinberg M, Sekikubo M, Biryabarema C, Money D. Assessing women's willingness to collect their own cervical samples for HPV 
testing as part of the ASPIRE cervical cancer screening project in Uganda. Int J Gynaecol Obstet. 2011;114(2):111-5. doi:10.1016/j.jpgo.2011.01.028,

15. Ogilvie GS, Mitchell S, Sekikubo M, Biryabarema C, Byamugisha J, Jeronimo J, et al. Results of a community-based cervical cancer screening pilot project using human papillomavirus self-sampling in Kampala, Uganda. Int J Gynaecol Obstet. 2013;122(2):118-23. doi:10.1016/j.ijgo.2013.03.019.

16. Mitchell S, Sekikubo M, Biryabarema C, Byamugisha J, Steinberg M, Jeronimo J, et al. Factors associated with high-risk HPV positivity in a low-resource setting in sub-Saharan Africa. Am J Obstet Gynecol. 2014;1(81):e1-7.

17. Teng FF, Mitchell SM, Sekikubo M, Biryabarema C, Byamugisha JK, Steinberg $M$ et al. Understanding the role of embarrassment in gynaecological screening: a qualitative study from the ASPIRE cervical cancer screening project in Uganda. BMJ Open. 2014;4(4). doi:10.1136/bmjopen-2014-004783.

18. Ezechi O, Gab-Okafor C, Ostergren P, Odberg PK. Willingness and acceptability of cervical cancer screening among HIV positive Nigerian women. BMC Public Health. 2013;13(1):1-8. doi:10.1186/1471-2458-13-46.

19. World Health Organization. WHO case definitions of HIV for surveillance and revised clinical staging and immunological classification of HIV-related disease in adults and children. 2007.

20. Rabiu KA AA, Adewunmi AA, Akinola OI, Wright KO. The need to incorporate routine cervical cancer counselling and screening in the management of HIV positive women in Nigeria. Asian Pac J Cancer Prev. 2011;12(5):1211-4

21. Wake RM, Rebe K, Burch VC. Patient perception of cervical screening among women living with human immuno-deficiency virus infection attending an antiretroviral therapy clinic in urban South Africa. J Obstet Gynaecol. 2009; 29(1):44-8. doi:10.1080/01443610802484070.

22. Moses E, Pedersen H, Mitchell S, Sekikubo M, Mwesigwa D, Singer J et al., editors. HPV prevalence and uptake of cervical cancer screening among HIV positive and negative women in a randomized controlled trial in Uganda. HPV 2015: 30th International Papillomavirus Conference. Lisbon: International Papillomavirus Society; 2015

23. Ogilvie G, Mitchell S, Sekikubo M, Biryabarema C, Byamugisha J, Krajden M, et al. Community based cervical cancer screening using self collection for HPV: results of the ASPIRE pilot project. Int J Gynecol Obstet. 2013;122(2): 118-23. doi:10.1016/j.jpgo.2013.03.019.

24. Moses E, Pedersen H, Mitchell S, Sekikubo M, Mwesigwa D, Singer J, et al. Uptake of community-based, self-collected HPV testing vs. visual inspection with acetic acid for cervical cancer screening in Kampala, Uganda: preliminary results of a randomised controlled trial. Tropical Med Int Health. 2015;20(10):1355-67. doi:10.1111/tmi.12549.

25. Smith JS, Green J, de Gonzalez AB, Appleby P, Peto J, Plummer M, et al. Cervical cancer and use of hormonal contraceptives: a systematic review. Lancet. 2003;361(9364):1159-67. http://dx.doi.org/10.1016/S01406736(03)12949-2

26. Moreno V, Bosch FX, Muñoz N, Meijer CJLM, Shah KV, Walboomers JMM et al. Effect of oral contraceptives on risk of cervical cancer in women with human papillomavirus infection: the IARC multicentric case-control study. Lancet. 2002;359(9312):1085-92. http://dx.doi.org/10.1016/S01406736(02)08150-3.

\section{Submit your next manuscript to BioMed Central and we will help you at every step:}

- We accept pre-submission inquiries

- Our selector tool helps you to find the most relevant journal

- We provide round the clock customer support

- Convenient online submission

- Thorough peer review

- Inclusion in PubMed and all major indexing services

- Maximum visibility for your research

Submit your manuscript at www biomedcentral.com/submit 